This document is confidential and is proprietary to the American Chemical Society and its authors. Do not copy or disclose without written permission. If you have received this item in error, notify the sender and delete all copies.

\title{
Savinase the most suitable enzyme for releasing peptides from lentil (Lens culinaris var. Castellana) protein concentrates with multifunctional properties
}

\begin{tabular}{|r|l|}
\hline Journal: & Journal of Agricultural and Food Chemistry \\
\hline Manuscript ID: & jf-2014-00849u.R1 \\
\hline Manuscript Type: & Article \\
\hline Date Submitted by the Author: & n/a \\
\hline Complete List of Authors: & $\begin{array}{l}\text { Garcia Mora, Patricia; ICTAN-CSIC, } \\
\text { Peñas, Elena; ICTAN-CSIC, } \\
\text { Frias, Juana; CSIC, Institute of Food Science, Technology and Nutrition } \\
\text { (ICTAN) } \\
\text { Martinez-Villaluenga, Cristina; CSIC, ICTAN }\end{array}$ \\
\hline
\end{tabular}


1 Savinase the most suitable enzyme for releasing peptides from lentil (Lens culinaris var.

2 Castellana) protein concentrates with multifunctional properties

3

4 Patricia Garcia-Mora, Elena Peñas, Juana Frias, Cristina Martínez-Villaluenga*

5

6 Department of Food Characterization, Quality and Safety; Institute of Food Science, Technology and

7 Nutrition (ICTAN-CSIC), Juan de la Cierva 3, 28006 Madrid, Spain

8

9 Corresponding author

10 *Email: c.m.villaluenga@,csic.es; Tlf: +34 912587601; Fax: +34 915644853

11

12

13

14

15

16

17

18

19

20

21

22

23

24 
ABSTRACT

The aim of this study was to produce multifunctional hydrolyzates from lentil protein concentrates.

27 Four different proteases (Alcalase, Savinase, Protamex and Corolase 7089) and different hydrolysis

28 times were evaluated for their degree and pattern of proteolysis, angiotensin I converting enzyme

29 (ACE)-inhibitory and antioxidant activities. Alcalase and Savinase showed the highest proteolytic 30 effectiveness $(\mathrm{P} \leq 0.05)$ which resulted in higher yield of peptides. The hydrolysate produced by Savinase

31 after $2 \mathrm{~h}$ of hydrolysis (S2) displayed the highest ACE-inhibitory $\left(\mathrm{IC}_{50}=0.18 \mathrm{mg} / \mathrm{mL}\right)$ and antioxidant

32 activity (1.22 $\mu \mathrm{mol}$ Trolox equivalents/mg protein). Subsequent RP-HPLC-MS/MS analysis of 3kDa

33 permeates of S2 showed 32 peptides mainly derived from convicilin, vicilin and legumin containing

34 amino acid sequences which makes them potential contributors to ACE-inhibitory and antioxidant

35 activities detected. The ACE-inhibitory and antioxidant activity of S2 were significantly improved after

36 in vitro gastrointestinal digestion $(\mathrm{P} \leq 0.05)$. Multifunctional hydrolysates could encourage value-added

37 utilization of lentil proteins for the formulation of functional foods and nutraceuticals.

41 Keywords: Lentil protein hydrolysates, alkaline proteases, antioxidant peptides, ACE inhibitory 42 peptides 


\section{INTRODUCTION}

Hypertension is a public health problem associated with cardiovascular complications affecting $25 \%$ adult population worldwide. ${ }^{1}$ Moreover, the increasing number of individuals with the metabolic syndrome is contributing to the rising prevalence of hypertension. In view to its high prevalence, pharmacotherapy, diet and lifestyle modifications are applied for treatment of hypertension. Inhibition of angiotensin I-converting enzyme (ACE, E.C. 3.4.15.1) has been used as a target therapy for treatment of hypertension. ${ }^{2}$ This enzyme plays a crucial role in the renin-angiotensin and kinin-kalicrein systems regulating blood pressure. ${ }^{3}$ Inhibition of ACE reduces the concentration of angiotensin II, a vasoconstrictor octapeptide, while it increases levels of the vasodilator peptide bradikinin which results in the lowering of blood pressure. ${ }^{2}$

A recent study has shown the increased participation of reactive oxygen species and reduced antioxidant enzymatic defense in the pathogenesis of hypertension. ${ }^{4}$ Oxidative stress affect several cellular signaling cascades and cellular functions ${ }^{5}$ reducing the bioavailability of nitric oxide, a vasodilatory molecule involved in the smooth muscle relaxation in the cardiovascular system. ${ }^{6}$ In addition, oxidation of membrane lipids brings about lipid peroxidation products, which damage proteins in the cardiovascular system. ${ }^{7}$ Therefore, amelioration of oxidative stress in addition to inhibition of ACE provides a multitarget therapy that may improve the clinical efficacy of pharmacological treatments for the management of hypertension and other cardiovascular disorders.

Because of the adverse side effects of the synthetic drugs, functional foods containing natural compounds are alternative strategies to drug therapy. ${ }^{8}$ Food-derived bioactive peptides with more than one bioactivity have multifunctional properties that can potentially be useful in targeting the multiple pathophysiological conditions underlying hypertension. ${ }^{9}$ Much research has been focused on the generation of peptides derived from animal and plant food proteins for the management of 
67 hypertension. ${ }^{10}$ To date, milk is the main source of ACE inhibitory peptides, in addition to egg, meat and fish. ${ }^{11}$ However, plant sources have gained less attention in this respect.

Lentil is a traditional pulse crop providing economic benefits in addition to the benefits derived from crop rotation, nitrogen fixation, and sustainable agriculture. ${ }^{12}$ Lentils are the staple food in many countries providing an inexpensive source of protein in the diet (20-30\%), however, they are largely underexploited for new emerging applications in the functional foods and nutraceutical areas. Previous studies have shown the potential of lentil proteins as source of ACE inhibitory peptides. ${ }^{13,14}$ In contrast, no studies have been conducted to produce multifunctional hydrolyzates from lentil proteins exhibiting both ACE-inhibitory and antioxidant activities so far, which would open up new possibilities for valueadded applications of lentil.

Bioactive peptides may be produced by enzymatic hydrolysis of food proteins with enzymes from microbial, plant or gastrointestinal origin. Several enzymes have been used to produce lentil hydrolyzates with bioactive properties such as Alcalase+Flavourzyme, bromelain, papain and gastrointestinal enzymes. $^{13,14}$ These studies have shown that ACE-inhibitory activity of lentil hydrolyzates strongly depends on protease specificity. Moreover, the release of bioactive peptides and consequently, the biological activity of protein hydrolyzates can be affected by operational conditions such as hydrolysis time. ${ }^{15}$ The objective of this work was to produce multifunctional lentil hydrolysates with ACE-inhibitory and antioxidant peptides. The effect of protease type and hydrolysis time on the proteolytic pattern, ACE-inhibitory and antioxidant activities of lentil hydrolysates was also studied. This information is critical for the development of value-added products, particularly as ingredient/s for the functional food and nutraceutical markets.

\section{MATERIALS AND METHODS}


Materials. Lentil seeds (Lens culinaris var. Castellana) were provided by Semillas Iglesias S. A.

91 (Salamanca, Spain) and stored in polyethylene bins at $4{ }^{\circ} \mathrm{C}$. Commercial food-grade enzymes Alcalase ${ }^{\circledR}$

92 2.4L FG, Savinase ${ }^{\circledR}$ and Protamex ${ }^{\circledR}$, were kindly provided by Novozymes (Bagsvaerd, Denmark).

93 Alcalase and Savinase are alkaline serine proteases from Bacillus licheniformis and Bacillus sp., 94 respectively. Protamex is a Bacillus protease complex consisting of sustilisin and neutral protease (E.C. 95 3.4.24.28). Corolase 7089 is a fungal neutral protease provided by AB Enzymes GmbH (Darmstadt,

96

Germany). Tripeptide Abz-Gly-Phe( $\left.\mathrm{NO}_{2}\right)$-Pro was purchased from Cymit-Quimica (Barcelona, Spain). All other chemicals were purchased from Sigma-Aldrich Quimica (Madrid, Spain) unless otherwise specified.

Preparation of lentil protein concentrates. Whole lentil seeds were ground using a coffee mill (Moulinex, Allençon, France) and passed through a 60-mesh sieve and $0.5 \mathrm{~mm}$ pore size. The lentil powders were stored at $-20{ }^{\circ} \mathrm{C}$ before use. Total protein concentration in lentil flour was determined as total nitrogen multiplied by 6.25 . Total nitrogen of lentil flours was analyzed in duplicate using a LECO TRUMAC apparatus (LECO Corp., St. Joseph, MI, USA).

Lentil protein concentrates were prepared using alkaline extraction. Briefly, lentil flour was suspended in water (solid-to-solvent ratio 1:10, w/v) and the $\mathrm{pH}$ value was adjusted to 8 . The suspension was stirred in an orbital shaker (Infors, Switzerland) at $20^{\circ} \mathrm{C}$ for $1 \mathrm{~h}$ and then, vacuum-filtered using a filter funnel (100-160 $\mu \mathrm{m}$ nominal pore size) to remove solids. Lastly, filtrates were freeze-dried and stored under vacuum and dark conditions in plastic bags at $-20^{\circ} \mathrm{C}$ until further analysis. The soluble protein concentration in the filtrates was determined by the DC Protein Assay (Bio-Rad Laboratories, Hercules, CA) following the manufacturer's protocol. Bovine serum albumin (BSA) was used as standard at a concentration range from 0 to $1 \mathrm{mg} / \mathrm{mL}$. 
Enzymatic proteolysis. Freeze-dried lentil protein concentrates were suspended in deionized water

$113(2 \%, w / v)$, equilibrated at $40{ }^{\circ} \mathrm{C}$ and the $\mathrm{pH}$ value adjusted to 8 with $0.1 \mathrm{M} \mathrm{NaOH}$. Enzymatic 114 proteolysis was carried out using an enzyme to substrate ratio (E/S) of $0.1 \mathrm{AU} / \mathrm{mg}$ of soluble protein at $11540{ }^{\circ} \mathrm{C}$ and $\mathrm{pH}$ 8. Aliquots were withdrawn at $0,1,2,3,4,5$, and $6 \mathrm{~h}$ from reaction mixtures and heated at $11680^{\circ} \mathrm{C}$ for $15 \mathrm{~min}$ for enzyme inactivation. Finally, hydrolyzates were centrifuged at $23,430 \mathrm{~g}$, at $10^{\circ} \mathrm{C}$ 117 for $10 \mathrm{~min}$, freeze-dried and stored at $-20{ }^{\circ} \mathrm{C}$ until use. Protein concentration was determined by the DC 118 protein assay (Bio-Rad). The samples were coded for protease type $(\mathrm{A}=$ Alcalase; $\mathrm{S}=\mathrm{Savinase} ; \mathrm{P}=$ 119 Protamex and $\mathrm{C}=$ Corolase 7089$)$ followed by hydrolysis time (1, 2, 3, 4, 5 and 6). For example, S2 120 hydrolyzates are those produced from lentil concentrate hydrolyzed by Savinase for $2 \mathrm{~h}$. Hydrolysis 121 were performed at least in triplicate for each enzyme.

122 Degree of hydrolysis (DH). The DH was calculated by determination of free amino groups by reaction 123 with 2,4,6-Trinitrobenzenesulfonic acid according to Adler-Nissen. ${ }^{16}$ Total number of amino groups in 124 lentil protein concentrate was determined after acid hydrolysis in $6 \mathrm{~N} \mathrm{HCl}$ at $110{ }^{\circ} \mathrm{C}$ for $24 \mathrm{~h}$ in vials 125 sealed under nitrogen. Analyses were performed in duplicate. Degree of hydrolysis was calculated using 126 the following equation:

$\mathrm{DH}(\%)=100 \times\left[\left(\mathrm{AN}_{2}-\mathrm{AN}_{1}\right) / \mathrm{N}_{\mathrm{pb}}\right]$

128 Where $\mathrm{AN}_{1}$ is the amino nitrogen content in the protein substrate before hydrolysis (mg tyrosine 129 equivalents/g protein), $\mathrm{AN}_{2}$ is the amino nitrogen content in the free protein in the protein substrate after 130 hydrolysis (mg tyrosine equivalents/g protein) and $\mathrm{N}_{\mathrm{pb}}$ is the total amino groups in the protein substrate 131 (mg tyrosine equivalents/g protein) as determined with $6 \mathrm{~N} \mathrm{HCl}$ at $110^{\circ} \mathrm{C}$ for $24 \mathrm{~h}$. Sodium dodecyl sulphate polyacrylamide gel electrophoresis (SDS-PAGE). SDS-PAGE 133 analysis of the protein hydrolyzates was performed on NuPAGE® Novex 4-12\% Bis-Tris Gels using the 134 XCell-sure lock Mini-Cell (Invitrogen, Madrid, Spain). Electrophoresis was carried out at 200 V. 
135 NuPAGE $\AA^{\circledR}$ MES-SDS and NuPAGE® LDS were used as running and sample buffers (Invitrogen), 136 respectively. Runs were carried out under non-reducing conditions in which 2-mercaptoethanol was 137 omitted in the denaturing buffer. Electrophoretic bands were stained with SimplyBlue SafeStain 138 (Invitrogen), followed by destaining in deionized water. The molecular weight of poly- and 139 oligopeptides was determined by comparison with the molecular weight marker solution Mark $12^{\mathrm{TM}}$ 140 (Invitrogen).

ACE-inhibitory activity. ACE-inhibitory activity of samples was measured in duplicate 142 following the fluorescence-based protocol of Sentandreu and Toldrá. ${ }^{17}$ The generated fluorescence was 143 read every minute for 30 min at emission and excitation wavelengths of 355 and 405 nm, respectively, 144 in a microplate fluorometer Synergy HT (Biotek, Winooski, VT, USA). IC 50 values expressed in protein 145 concentration $(\mathrm{mg} / \mathrm{mL})$ were calculated for the most active hydrolyzates. $\mathrm{IC}_{50}$ was determined by dose146 response curves in which the range of protein concentration $(0-0.5 \mathrm{mg} / \mathrm{mL})$ was distributed in a 147 logarithmic scale and using the non-linear regression sigmoidal curve fit function in GraphPad Prism 1484.00 (Graphpad Software Inc., San Diego, CA, USA). Protein concentration of 3 kDa permeates was 149 measured by DC protein assay (Biorad).

150 Oxygen radical absorbance capacity (ORAC). ORAC of samples was measured in duplicate 151 by fluorescence as described previously. ${ }^{18}$ Results were expressed as $\mu$ mol Trolox equivalents (TE)/ mg 152 protein $(\mu \mathrm{mol} \mathrm{TE} / \mathrm{mg}$ protein).

Proteomic analyses. Matrix-assisted laser desorption/ionization time of flight (MALDI-TOF) 154 analysis were performed for the most active hydrolyzates. Peptide mass fingerprint was performed in a 155 Voyager-DE PRO mass spectrometer (Applied Biosystems, Foster City, CA) equipped with a pulsed $156337 \mathrm{~nm}$ nitrogen laser (1 ns pulse width and $3 \mathrm{~Hz}$ frequency) which was operated in the reflectror mode 157 for positive ions. Parameters of the instrument were as follows: an acceleration voltage of $20 \mathrm{kV}$, an 
158

159

160

161

162

163

164

165

166

167

168

169

170

171

172

173

174

175

176

177

178

179

180

extraction voltage of ions generated by the laser desorption were introduced into a time of flight analyser (1.3 m flight path) with an acceleration voltage of $20 \mathrm{kV}, 76 \%$ grid voltage, $0.001 \%$ ion guide wire voltage, and a delayed extraction time of $400 \mathrm{~ns}$. The samples were mixed with the matrix at a ratio of 1:5 (v/v), and $1 \mu \mathrm{L}$ of this solution was spotted onto a flat stainless-steel sample plate and dried in air.

Mass spectra were obtained over de $\mathrm{m} / \mathrm{z}$ range 500-4000. External mass calibration was applied using the monoisotopic $[\mathrm{M}+\mathrm{H}]+$ values of des- $\operatorname{Arg}^{1}$ Bradykinin, Angiotensin I, Insuline, Glu ${ }^{1}$-Fibrinopeptide B, adrenocorticotropic hormone fragments 1-17, 18-39, and 7-38.

For peptide identification, $10 \mu \mathrm{g}$ of the most active hydrolysate were desalted using a reverse phase $\left(\right.$ PorosR $^{\oplus}$ ) chromatography with $80 \%$ acetonitrile (ACN)/0.1\% trifluoroacetic acid (TFA). Later, the peptides were dried and resuspended with $10 \mu \mathrm{L} 0.1 \%$ TFA. An aliquot of $5 \mu \mathrm{l}$ of resuspended sample were injected in the Linear Trap Quadrupole (LTQ) Orbitrap Velos (Thermo Scientific). Peptides were loaded onto a C18-A1 ASY-Column $2 \mathrm{~cm}$ precolumn (Thermo Scientific) and then eluted onto a Biosphere $\mathrm{C} 18$ column (C18, inner diameter $75 \mu \mathrm{m}, 15 \mathrm{~cm}$ long, $3 \mu \mathrm{m}$ particle size) (NanoSeparations) at a flow rate of $250 \mathrm{~nL} / \mathrm{min}$ on a nanoEasy high-performance liquid chromatography (Proxeon) coupled to a nanoelectrospay ion source (Proxeon).

The mobile phases used consisted of $0.1 \%$ formic acid $/ 2 \% \mathrm{ACN}$ (solvent $\mathrm{A}$ ) and $0.1 \%$ formic acid in $100 \% \mathrm{ACN}$ (solvent B). The solvent gradient was from $100 \% \mathrm{~A}$ to $35 \% \mathrm{~B}$ in $140 \mathrm{~min}$. Mass spectra were acquired in the positive ion mode. Full-scan MS spectra (m/z 400-1800) were acquired with a target value of 1,000,000 at a resolution of 30,000 at $\mathrm{m} / \mathrm{z} 400$ and the 15 most intense ions were selected for collision induced dissociation fragmentation in the LTQ with a target value of 10,000 and normalized collision energy of 38\%. Precursor ion charge state screening and monoisotopic precursor selection were enabled. Singly charged ions and unassigned charge states were rejected. Dynamic exclusion was enabled with a repeat count of 1 and exclusion duration of $30 \mathrm{~s}$. 

database, taxonomy Viridiplantae (1530236 sequences sequences) and a home-made database with the Lens culinaris entries in UniProt (336 sequences, 75114 residues). Database search parameters used were the following: peptide tolerance, $10 \mathrm{ppm}$; fragment ion tolerance, $0.8 \mathrm{Da}$; none enzyme and variable modification, methionine oxidation. In all peptide identification, the probability scores were greater than the score fixed by Mascot as significant with a p-value minor than 0.05 . The automatic decoy database search function of Protein Discover was enabled to allow estimation of false discovery rate (FDR). Sequence identification with reported biological activity was compared with bioactive peptides sequences submitted to the

BIOPEP database (http://www.uwm.edu.pl/biochemia/index.php/pl/biopep).

191 In vitro gastrointestinal digestion. Lentil hydrolyzates produced by selected protease type and hydrolysis time were further subjected to simulated gastrointestinal digestion by sequential hydrolysis using pepsin and pancreatin. ${ }^{19}$ Digestions were stopped by heating samples in boiling water for 10 min. Samples were stored at $-20{ }^{\circ} \mathrm{C}$ and then freeze-dried. Protein content was determined for each sample using the DC Protein Assay (Biorad).

Statistical analysis. Data were subjected to one-way analysis of variance (ANOVA) by Statgraphics between samples were compared by using a Duncan's multiple-range test at $\mathrm{P} \leq 0.05$ probability levels.

\section{RESULTS AND DISCUSSION}

Protein content of lentil flour $(27.4 \pm 0.1 \%$ on dry basis $)$ was within the range of reported values

202 for lentil flours. ${ }^{20}$ Alkaline extraction at $\mathrm{pH} 8$ led to $80 \%$ extraction of total protein. Thus, protein 203 content of lentil var. Castellana protein concentrate was $75.54 \pm 0.2 \%$ on dry basis which was comparable 
204 to previous data for red and green lentil protein concentrates $(78.2 \pm 0.2,79.1 \pm 0.3 \%){ }^{21}$ The obtained 205 lentil protein concentrate was hydrolyzed by different enzymes (Alcalase, Savinase, Protamex and 206 Corolase 7089) for screening the most effective one hydrolyzing lentil proteins and releasing ACE207 inhibitory and antioxidant peptides.

Proteolytic pattern of hydrolysis. To evaluate the hydrolysis efficiency, the degree of hydrolysis (DH) value is a widely used criterion as it is highly related to the hydrolytic process yield. Figure 1 shows the effect of protease type and hydrolysis time in the DH of lentil proteins. DH values increased 211 gradually reaching a plateau at $5 \mathrm{~h}$ for Alcalase, Savinase and Protamex $(23 \%, 15 \%, 11 \%)$ and $4 \mathrm{~h}$ for 212 Corolase 7089 (10\%). The significant differences $(\mathrm{P} \leq 0.05)$ found among $\mathrm{DH}$ values of lentil 213 hydrolyzates may be attributed to different enzyme specificity. ${ }^{22}$ Subtilisins have a broad specificity 214 which explains its higher proteolytic efficiency compared to Protamex and Corolase 7089. Our results 215 agree with previous studies outstanding the ability of Alcalase to produce protein hydrolyzates with 216 higher DH than other enzymes. ${ }^{23}$ Maximum DH observed in the present study for Alcalase hydrolyzates $217(23 \%)$ is comparable to those reported in earlier studies for other legume proteins. ${ }^{24,25}$ In contrast, the 218 degree of hydrolysis of cowpea and bean proteins by Alcalase was found significantly different from 219 lentil proteins (35.7 and 14\%, respectively) ..$^{26,27}$ These differences in the susceptibility of lentil proteins 220 to hydrolysis might be attributed to their particular structure. ${ }^{28}$ Enzymatic treatments with sequential 221 addition of Alcalase $(1 \mathrm{~h})$ and Flavourzyme $(1.5 \mathrm{~h})$ have also been used to increase the proteolytic 222 efficiency in the production of lentil hydrolyzates. ${ }^{29}$ In this case, high DH values were obtained (58 and $22364 \%$ for red and green lentil proteins, respectively); however, extensive proteolysis is not recommended 224 because peptides generated may produce bitterness and worsen important technological properties 225 required for particular food industry applications. 
Figure 2 shows the electrophoretic profiles of lentil hydrolyzates produced by Alcalase (Panel A), Savinase (Panel B), Protamex (Panel C) and Corolase 7089 (Panel D). Non-hydrolysed protein concentrate (Figure 2 panels A, B, C and D; Lane 2) showed nine intense bands with apparent molecular masses (MM) from 14.4 to $95 \mathrm{kDa}$. The major bands found in lentil concentrate had estimated MM of 50 and $65 \mathrm{kDa}$, which probably correspond to subunits of vicilin (48 kDa) and convicilin $(63 \mathrm{kDa})$, respectively. ${ }^{30}$ Other bands with lower $\mathrm{MM}$ of 40,20 and $<15 \mathrm{kDa}$ were considered to belong to $11 \mathrm{~S}$ acidic subunit, $11 \mathrm{~S}$ basic subunit and a mixture of $\gamma$-vicilin and albumin polypeptides, respectively. ${ }^{31}$ The electrophoretic profile of protein concentrates from lentil var. Castellana was similar to that reported for green and red lentil concentrates. ${ }^{13}$ Major polypeptides found in lentil protein concentrate were readily hydrolysed by Alcalase to small peptides $<10 \mathrm{kDa}$ after $1 \mathrm{~h}$ (Figure 2A; Lane 3). Longer hydrolysis time from 4 to $6 \mathrm{~h}$ induced further breakdown of peptide bonds and formation of much smaller fractions at $\mathrm{MM}<6 \mathrm{kDa}$ (Figure 2A; Lanes 6-8). Our results agree with previous studies in which Alcalase digestion was efficient in producing small peptides with MM below $10 \mathrm{kDa}$ from chickpea, ${ }^{24}$ and bean $^{26,31}$ proteins. In addition, sequential use of Alcalase and Flavorzyme to produce peptides from lentil proteins have been proven more effective than the use of gastrointestinal enzymes, papain and bromelain. ${ }^{13}$ Similarly to Alcalase, protein digestion by Savinase was also efficient. A sharply reduction of most polypeptides $(30,40,50,55$ and $65 \mathrm{kDa})$ present in lentil protein concentrate was observed after $1 \mathrm{~h}$ of hydrolysis appearing of new bands under $14 \mathrm{kDa}$ (Figure 2B; Lane 3). As the 244 hydrolysis progressed, polypeptides with estimated MM at 50, 55, $65 \mathrm{kDa}$ were completely degraded 245 (Figure 2B; Lanes 4-8). In addition, the reduction of intensity of bands with $\mathrm{MM}<14 \mathrm{kDa}$ suggested 246 further degradation of the peptides into much smaller fragments. In contrast, Protamex and Corolase 2477089 digestions were not as efficient as Alcalase and Savinase digestions in consistency with DH values 248 (Figure 2C and 2D). Protamex digestion completely degraded high- and medium-molecular weight 
polypeptides (estimated MM at 30,37,60,67, $90 \mathrm{kDa}$ ) within $1 \mathrm{~h}$ (Figure 2C; Lane 3). As consequence, the appearance of some bands between 30 and $20 \mathrm{kDa}$ and $<10 \mathrm{kDa}$ was observed. Further treatment with Protamex resulted in slight changes in the digest profile such as the disappearance of some bands with apparent $\mathrm{MM}$ between 30 and $20 \mathrm{kDa}$, and the increase in the intensity of fraction $<10 \mathrm{kDa}$ (Figure 2C; Lanes 4-8). Finally, Corolase 7089 treatment decreased the intensity of bands with MM of 50, 55, $67 \mathrm{kDa}$ while the appearance of lower MM bands at 25 and $28 \mathrm{kDa}$ and under $6 \mathrm{kDa}$ were observed after $1 \mathrm{~h}$ (Figure 2D; Lane 3). Longer digestion time had little impact on the SDS-PAGE profiles in which only the increased intensity in the fraction under $6 \mathrm{kDa}$ was observed (Figure 2D; Lanes 4-8). Resistance of lentil and other legume proteins to proteases such as Protamex and Corolase 7089 has not been reported previously.

ACE inhibitory activity of lentil protein hydrolysates. ACE-inhibitory peptides are generally short amino acid sequences since the active site of ACE cannot accommodate large peptide molecules. ${ }^{32}$ 261 Therefore, samples were ultrafiltrated through $3 \mathrm{kDa}$ cutoff membrane and permeate was used for ACE262 inhibitory analysis. Non-hydrolyzed lentil protein concentrate showed a weak ACE-inhibitory activity 263 (20\% inhibition). ACE-inhibitory activity of hydrolyzates was significantly affected by the protease 264 used and hydrolysis time (Table 1). Alcalase and Savinase hydrolyzates exhibited higher ACE inhibition 265 (64-71\% and 56-63\%, respectively) than Protamex (31-46\%) and Corolase 7089 (28-50\%) digests, 266 regardless of hydrolysis time. ACE-inhibitory efficacy is directly associated with chain length and 267 peptide sequence. Short peptide chains containing between 3-12 amino acid residues and Tyr, Phe and 268 Pro or hydrophobic amino acids are reported to be the most favorable sequences for ACE inhibition. ${ }^{10}$ 269 Alcalase and Savinase produced hydrolyzates with higher yield of shorter peptide sequences (Figure 2A 270 and $2 \mathrm{~B}$ ) that joined to their specificity for aromatic or hydrophobic residues at position $\mathrm{P} 1^{22}$ is consistent 271 with their higher ACE-inhibitory efficacy. ACE-inhibitory activity of hydrolyzates gradually increased 
$272(\mathrm{P} \leq 0.05)$ reaching maximum values after $1-3 \mathrm{~h}$ depending on the enzyme, while this activity decreased 273 with extended hydrolysis time $(\mathrm{P} \leq 0.05)$ likely due to active amino acid sequences were cleaved by 274 protease. $\mathrm{IC}_{50}$ values were calculated for A3 and S2 hydrolyzates, selected for their highest ACE275 inhibitory activities. The selected hydrolysis time ( $3 \mathrm{~h}$ for Alcalase and $2 \mathrm{~h}$ for Savinase) was chosen 276 because no significant improvements were found with further digestion times $(\mathrm{P} \geq 0.05)$. The A3 and S2 277 hydrolyzates exhibited significantly different $(\mathrm{P} \leq 0.05) \mathrm{IC}_{50}$ values of $0.25 \pm 0.02 \mathrm{mg}$ protein $/ \mathrm{mL}$ and $0.18 \pm 0.02 \mathrm{mg}$ protein $/ \mathrm{mL}$, respectively. It is worth noting the considerably higher ACE inhibitory activity of S2 hydrolyzates compared to A3 hydrolyzates $(\mathrm{P} \leq 0.05)$. These results suggest that Savinase should generate peptides with most favorable amino acid sequences than Alcalase. As far as we know, this is the first evidence showing the effectiveness of Savinase in releasing ACE-inhibitory peptides from legume proteins. $\mathrm{IC}_{50}$ values of $\mathrm{ACE}$-inhibitory peptides in $\mathrm{A} 3$ and $\mathrm{S} 2$ hydrolyzates are higher when compared to activities of peptides released from lentil proteins by gastrointestinal enzymes $(0.43-$ $0.89 \mathrm{mg} / \mathrm{mL}) .{ }^{14,33,34}$ Moreover, the ACE-inhibitory activity of S2 hydrolyzates found in this work is within the range of reported $\mathrm{IC}_{50}$ values for red and green lentil concentrates hydrolyzed by Alcalase/Flavourzyme, bromelain and papain $(0.19-0.08 \mathrm{mg} / \mathrm{mL})$, although it is noteworthy that much longer hydrolysis time $(8 \mathrm{~h})$ were used in the case of both plant proteases. ${ }^{13}$ The ACE-inhibitory activity of A3 and S2 hydrolyzates are quite promising in comparison to activities reported for Alcalase hydrolyzates from different legumes such as cowpea, chickpea, mung bean and soybean exhibiting $\mathrm{IC}_{50}$ values ranging from 2.5 to $0.13 \mathrm{mg} / \mathrm{mL}^{23,25,27,35}$ type on the potential antioxidant activity of lentil hydrolyzates was determined using the ORAC-FL method which reflects the peroxyl radical scavenging activity. ${ }^{36}$ Antioxidant mechanism assayed with 294 ORAC method is based on a hydrogen atom transfer mechanism. A radical initiator is used to generate 
295 peroxyl radical $\mathrm{ROO}^{\circ}$ that abstracts a hydrogen atom from antioxidant molecules present in the sample. 296 Results in Table 2 indicate that ORAC values of non-hydrolyzed lentil proteins were significantly lower 297 compared to lentil hydrolyzates $(\mathrm{P} \leq 0.05)$. Hydrolysis time and protease used greatly affected the radical 298 scavenging activity of lentil protein hydrolyzates. Hydrolyzates produced using Alcalase, Savinase and 299 Corolase 7089 displayed a gradual increase in peroxyl scavenging activity reaching the highest values 300 after 4, 2 and 3 h, respectively $(\mathrm{P} \leq 0.05)$. In contrast, Protamex hydrolyzates showed the highest activity $301(\mathrm{P} \leq 0.05)$ at the shortest time $(1 \mathrm{~h})$, after which a gradual decrease was observed $(\mathrm{P} \leq 0.05)$. The 302 differences in antioxidant activity observed at different hydrolysis times could be attributable to the 303 different peptides and amino acid sequences released during hydrolysis. This leads to a difference in 304 their ability to act as donors of hydrogen atoms that may inhibit oxidative chain reactions or prevent 305 their initiation. Higher antioxidant activity potential of A4 and S2 hydrolyzates may be explained by the 306 higher efficiency of Alcalase and Savinase producing smaller peptides (Figures 2A and 2B). The 307 molecular weight of peptides is believed to play a key role in scavenging oxygen radicals. Recent 308 studies pointed out that cowpea and bean protein hydrolyzates radical scavenging activity increased with 309 decreasing molecular weight. ${ }^{27,37}$ In fact, identified antioxidant peptides derived from food proteins are 310 composed of 2-16 amino acid residues. ${ }^{38}$ The higher efficiency of subtilases in releasing peroxyl 311 scavenging peptides observed in the present study is consistent with their preferential specificity to 312 cleave hydrophobic amino acids which have been shown to act as proton donors. ${ }^{39}$ Comparison of the 313 ORAC values showed that S2 hydrolyzate exhibited the highest peroxyl scavenging activity $(0.8 \mu$ mol $314 \mathrm{TE} / \mathrm{mg}$ protein $)$ followed by A4 hydrolyzate $(0.7 \mu \mathrm{mol} \mathrm{TE} / \mathrm{mg}$ protein $)$. These results indicate that 315 Savinase release antioxidant peptides with more favorable amino acid sequences than Alcalase. The 316 ORAC values of permeates $<3 \mathrm{kDa}$ from S2 and A4 hydrolyzates was also analyzed. Radical 317 scavenging activity was 2-fold higher in these fractions compared to whole hydrolyzates. A4 permeates 
318 exhibited $0.91 \pm 0.05 \mu \mathrm{mol} \mathrm{TE} / \mathrm{mg}$ protein and S2 permeates exhibited $1.22 \pm 0.06 \mu \mathrm{mol} \mathrm{TE} / \mathrm{mg}$ protein 319 suggesting that short peptides may be responsible for the potential antioxidant activity of protein 320 hydrolyzates in agreement with previous studies. ${ }^{27,}{ }^{37}$ To our knowledge, this is the first study on the 321 production of hydrolyzates with antioxidant activity from lentil proteins. The antioxidant activity 322 measured by ORAC-FL method of A4 and S2 hydrolyzates was more than two times higher compared 323 to Alcalase hydrolyzates from different soybean cultivars. ${ }^{40}$ In addition, lentil hydrolyzates produced by 324 subtilases in the present study exhibited ORAC values within the range of reported values for common 325 vegetables (green pepper, spinach, purple onion, broccoli, beet and cauliflower) considered as leading 326 sources of antioxidant activity against peroxyl radicals (0.023-0.3 $\mu \mathrm{mol} \mathrm{TE} / \mathrm{mg}$ d.w.). ${ }^{36}$ the $3 \mathrm{kDa}$ permeate of A4 and S2 hydrolyzates. Comparison of the spectra showed similarities between A4 and S2 hydrolyzates such as the presence of high intensity signals (m/z 1251.1-1255.5, m/z 1325.51327.5, m/z 1340.5-1342.5, m/z 1652.8-1657.8 and m/z 2004.0-2007.1) referred to either matrix related clusters or peptides that could represent concomitants including non-specific digestion products. ${ }^{41,42}$ It is worth noting that A4 and S2 hydrolyzates showed differential peptide masses with reduced intensity (see

334 the inset mass peptide list in Figure 3). The different peptide profile observed for A4 and S2 335 hydrolyzates indicates that Alcalase and Savinase have different enzyme specificity which is consistent 336 with the above mentioned results. identification based on its higher ACE-inhibitory and antioxidant activities and the $3 \mathrm{kDa}$ permeate was Identification of bioactive multifunctional peptides. S2 hydrolysate was selected for peptide analyzed by RP-HPLC-MS/MS. Table 3 shows the list of peptides identified containing in part of their structure amino acid sequences with reported ACE-inhibitory (bolded sequences) and antioxidant 
341 activity (underlined sequences) according to BIOPEP database. Identified peptides were fragments 342 derived from lentil storage proteins (convicilin, vicilin, legumin and albumin), allergen Len c 1 and 343 lectin having at the C-terminus residues such as alanine (A), valine (V), leucine (L), tyrosine (Y), 344 phenylalanine (F) and tryptophan (W). The presence of some of these amino acids in ultimate position 345 fulfils the rule proposed by Cheung et al. ${ }^{43}$ about residues being preferred for ACE inhibitors and 346 substrates. Moreover, peptides identified were characterized by the presence of several hydrophobic 347 amino acids such as Ala (A), Pro (P). Val (V), Ile (I) Leu (L), Phe (F) Trp (W), Tyr (Y) and Met (M) 348 which may act as proton donors ${ }^{39}$ Specifically, Tyr (Y) and Trp (W) have been reported as the main 349 responsible for the antioxidant activity of peptides in the ORAC-FL model. ${ }^{42,45}$ In some peptides His 350 (H) was also found which has been commonly associated with antioxidant activity due to its hydrogen351 donating and radical-trapping imidazol ring. ${ }^{39}$ Taking all together, the identification of the amino acid 352 sequence of peptides in Savinase lentil hydrolysates have demonstrated their multifunctional properties 353 that could make an important contribution in dietary interventions for prevention/therapy of 354 hypertension. This is the first study showing an exhaustive characterization of the peptide fraction of 355 lentil protein hydrolysates. So far, only three ACE-inhibitory peptides (KLRT, TLHGMV and VNRLM) 356 released by sequential pepsin-pancreatin hydrolysis from lentil proteins were identified ${ }^{33}$ and none of 357 them were identified in the present work.

Stability of ACE-inhibitory and antioxidant peptides in selected lentil hydrolyzate to gastrointestinal digestion. There are numerous in vivo studies in animal models of hypertension and 360 human clinical studies in hypertensive patients showing that oral administration of bioactive peptides 361 from food proteins with ACE-inhibitory activity or foods containing them outcomes in the reduction of 362 hypertension. $^{46}$ This body of evidence demonstrates that ACE-inhibitory peptides can resist 363 gastrointestinal digestion to be absorbed in the intestine and ultimately reach the target molecule. 
364 Nevertheless, gastrointestinal enzymes may cause structural degradation of bioactive peptides and loss 365 of their bioactivity. Therefore, it is important to determine their stability to gastrointestinal digestion. 366 For this purpose, the most potent peptide fraction ( $3 \mathrm{kDa}$ permeate of $\mathrm{S} 2$ hydrolyzate) were further 367 sequentially digested with pepsin and pancreatin to simulate gastrointestinal digestion. Some studies 368 have reported a relation between peptide structure and bioavailability, thus, small hydrophobic peptides 369 tend to be resistant to gastrointestinal digestion and, therefore, are generally absorbed. ${ }^{47}$ Accordingly, 370 based on the cleavage mechanism of Savinase, lentil hydrolyzates produced in the present study were hydrophobic and with molecular masses below $3 \mathrm{kDa}$, which support the potential bioavailability of such hydrolyzates. Figure 4 shows ACE-inhibitory and antioxidant activities of 3 kDa permeate of S2 hydrolyzate before and after in vitro gastrointestinal digestion. When peptides were subjected to in vitro gastrointestinal digestion $\mathrm{IC}_{50}$ was slightly lower $(0.14 \mathrm{mg}$ protein $/ \mathrm{mL})$ compared to that before digestion which indicates a higher ACE-inhibitory potency $(0.18 \mathrm{mg}$ protein $/ \mathrm{mL})(\mathrm{P} \leq 0.05)$. In addition, antioxidant activity of peptides in the $3 \mathrm{kDa}$ fraction increased 3 times after gastrointestinal digestion $(\mathrm{P} \leq 0.05)$. These results suggest that peptides in $\mathrm{S} 2$ hydrolyzates were either resistant or liberated new fragments with ACE-inhibitory and antioxidant activity after simulated gastrointestinal digestion. As consequence, peptides in S2 hydrolysate could preserve or improve its multifunctionality in the gastrointestinal tract.

In conclusion, this study reveals that subtilisins are the most suitable enzymes for lentil proteolysis and production of hydrolysates with ACE-inhibitory and antioxidant activities. The highest ACE-inhibitory and antioxidant activities were found in lentil hydrolysates treated with Savinase for $2 \mathrm{~h}$ at $40{ }^{\circ} \mathrm{C}$. Therefore, Savinase is the best choice for a cost-effective production of lentil multifunctional hydrolysates. Several peptides with amino acid sequences rich in hydrophobic amino acids were identified in these hydrolysates which make them potential contributors to the dual bioactivity detected. 
387 Multifunctional hydrolyzates could encourage value-added utilization of lentil proteins as functional 388 ingredients of nutraceuticals for prevention of hypertension and cardiovascular diseases.

$390 \quad$ Funding

391 This work was funded by the AGL2010-16310 project from the MINECO (Ministerio de Economía y 392 Competitividad from Spain).

$393 \quad$ Notes

394 The authors declare no conflict of interest.

395

396 ABBREVIATIONS LIST

397 ACE: angiotensin I-converting enzyme; ACN: acetonitrile; DH: degree of hydrolysis; HPLC: high 398 performance liquid chromatography with photodiode array detection; LTQ: linear trap quadrupole; 399 MALDITOF: matrix-assisted laser desorption/ionization time of flight; MM: Molecular mass; ORAC: 400 oxygen radical absorbance capacity; SDS-PAGE: sodium dodecyl sulfate polyacrylamide gel 401 electrophoresis; TE: Trolox equivalents; TFA: trifluoroacetic acid

\section{ACKNOWLEDGEMENTS}

404 This work was funded by the AGL2010-16310 project from the MINECO (Ministerio de 405 Economía y Competitividad from Spain). The authors wish to thank MINECO for granting Patricia 406 García Mora predoctoral fellowship

407

408

\section{REFERENCES}

409 (1) World and Health Organization (WHO). Cardiovascular diseases (CVDs). 2009 (Access date: 03 410 September 2013). 
411 (2) Hong, F.; Ming, L.; Yi, S.; Zhanxia, L.; Yongquan, W.; Chi, L., The antihypertensive effect of 412 peptides: a novel alternative to drugs? Peptides 2008, 29, 1062-1071.

413 (3) Skeggs, L. T.; Dorer, F. E.; Levine, M.; Lentz, K. E.; Kahn, J. R., The biochemistry of the renin414 angiotensin system. Adv. Exp. Med. Biol. 1980, 130, 1-27.

415 (4) Bagatini, M. D.; Martins, C. C.; Battisti, V.; Gasparetto, D.; da Rosa, C. S.; Spanevello, R. M.; 416 Ahmed, M.; Schmatz, R.; Chitolina Schetinger, M. R.; Morsch, V. M., Oxidative stress versus 417 antioxidant defenses in patients with acute myocardial infarction. Heart Vessels 2011, 26, 55-63.

418 (5) Ray, P. D.; Huang, B.-W.; Tsuji, Y., Reactive oxygen species (ROS) homeostasis and redox 419 regulation in cellular signaling. Cell Signal 2012, 24, 981-990.

420 (6) Toeroek, J., Participation of Nitric Oxide in Different Models of Experimental Hypertension. $421 \quad$ Physiol. Res. 2008, 57, 813-825.

422 (7) Mattson, M. P., Roles of the lipid peroxidation product 4-hydroxynonenal in obesity, the 423 metabolic syndrome, and associated vascular and neurodegenerative disorders. Exp. Gerontol. 2009, 44, $424 \quad 625-633$.

425 (8) Agyei, D.; Danquah, M. K., Industrial-scale manufacturing of pharmaceutical-grade bioactive 426 peptides. Biotechnol. Adv. 2011, 29, 272-277.

427 (9) Udenigwe, C. C.; Aluko, R. E. Multifunctional cationic peptide fractions from flaxseed protein 428 hydrolysates. Plant Foods Hum. Nutr. 2012, 67, 1-9.

429 (10) Erdmann, K.; Cheung, B. W. Y.; Schroeder, H., The possible roles of food-derived bioactive peptides in 430 reducing the risk of cardiovascular disease. J. Nutr. Biochem. 2008, 19, 643-654.

431 (11) Hernandez-Ledesma, B.; del Mar Contreras, M.; Recio, I., Antihypertensive peptides: 432 Production, bioavailability and incorporation into foods. Adv. Colloid Interfac. Sci. 2011, 165, 23-35.

433 (12) Nothern Pulse Growers Association. (http://www.northernpulse.com/growers/). (Access date: 19 434 September 2013). 
435 (13) Barbana, C.; Boye, J. I., Angiotensin I-converting enzyme inhibitory properties of lentil protein 436 hydrolysates: Determination of the kinetics of inhibition. Food Chem. 2011, 127, 94-101.

437 (14) Boye, J. I.; Roufik, S.; Pesta, N.; Barbana, C., Angiotensin I-converting enzyme inhibitory 438 properties and SDS-PAGE of red lentil protein hydrolysates. Food Sci. Technol. 2010, 43, 987-991.

439 (15) Contreras, M. M.; Hernandez-Ledesma, B.; Amigo, L.; Martin-Alvarez, P. J.; Recio, I., 440 Production of antioxidant hydrolyzates from a whey protein concentrate with thermolysin: optimization 441 by response surface methodology. Food Sci. Technol. 2011, 44, 9-15.

442 (16) Adler-Nissen, J., Determination of the degree of hydrolysis of food protein hydrolysates by 443 trinitrobenzenesulfonic acid. J. Agric. Food Chem. 1979, 27, 1256-1262.

444 (17) Sentandreu, M. Á.; Toldrá, F., A fluorescence-based protocol for quantifying angiotensin445 converting enzyme activity. Nat. Protoc. 2006, 1, 2423-2427.

446 (18) Torino, M. I.; Limon, R. I.; Martinez-Villaluenga, C.; Makinen, S.; Pihlanto, A.; Vidal-Valverde, 447 C.; Frias, J., Antioxidant and antihypertensive properties of liquid and solid state fermented lentils. Food 448 Chem. 2013, 136, 1030-1037.

449 (19) Moreno, F. J.; Mellon, F. A.; Wickham, M. S. J.; Bottrill, A. R.; Mills, E. N. C., Stability of the 450 major allergen Brazil nut $2 \mathrm{~S}$ albumin (Ber e 1) to physiologically relevant in vitro gastrointestinal 451 digestion. FEBS J. 2005, 272, 341-352.

452 (20) Roy, F.; Boye, J. I.; Simpson, B. K., Bioactive proteins and peptides in pulse crops: Pea, 453 chickpea and lentil. Food Res. Int. 2010, 43, 432-442.

454 (21) Barbana, C.; Boucher, A. C.; Boye, J. I., In vitro binding of bile salts by lentil flours, lentil 455 protein concentrates and lentil protein hydrolysates. Food Res. Int. 2011, 44, 174-180.

456 (22) Gupta, R.; Beg, Q. K.; Lorenz, P., Bacterial alkaline proteases: molecular approaches and 457 industrial applications. App. Microbiol. Biot. 2002, 59, 15-32. 
(23) Medina-Godoy, S.; Ambriz-Perez, D. L.; Fuentes-Gutierrez, C. I.; German-Baez, L. J.; Gutierrez-Dorado, R.; Reyes-Moreno, C.; Valdez-Ortiz, A., Angiotensin-converting enzyme inhibitory and antioxidative activities and functional characterization of protein hydrolysates of hard-to-cook chickpeas. J. Sci. Food Agric. 2012, 92, 1974-1981.

(24) Yust, M. M.; Pedroche, J.; Giron-Calle, J.; Alaiz, M.; Millan, F.; Vioque, J., Production of ace inhibitory peptides by digestion of chickpea legumin with alcalase. Food Chem. 2003, 81, 363-369.

(25) Li, G. H.; Le, G. W.; Liu, H.; Shi, Y. H., Mung-bean protein hydrolysates obtained with alcalase exhibit angiotensin I-converting enzyme inhibitory activity. Food Sci. Technol. Int. 2005, 11, 281-287.

(26) Rui, X.; Boye, J. I.; Simpson, B. K.; Prasher, S. O., Angiotensin I-converting enzyme inhibitory properties of Phaseolus vulgaris bean hydrolysates: Effects of different thermal and enzymatic digestion treatments. Food Res. Int. 2012, 49, 739-746.

(27) Segura Campos, M. R.; Chel Guerrero, L. A.; Betancur Ancona, D. A., Angiotensin-I converting enzyme inhibitory and antioxidant activities of peptide fractions extracted by ultrafiltration of cowpea Vigna unguiculata hydrolysates. J. Sci. Food Agric. 2010, 90, 2512-2518.

(28) Durak, A.; Baraniak, B.; Jakubczyk, A.; Swieca, M., Biologically active peptides obtained by enzymatic hydrolysis of Adzuki bean seeds. Food Chem. 2013, 141, 2177-2183.

(29) van der Ven, C.; Gruppen, H.; de Bont, D. B. A.; Voragen, A. G. J., Reversed phase and size exclusion chromatography of milk protein hydrolysates: relation between elution from reversed phase column and apparent molecular weight distribution. Int. Dairy J. 2001, 11, 83-92.

(30) ExPASy: Bioinformatic resource portal. (www.expasy.org) (Accesed date: 13 July 2013).

(31) Hernandez-Alvarez, J. A.; Carrasco-Castilla, J.; Davila-Ortiz, G.; Alaiz, M.; Giron-Calle, J.; Vioque-Pena, J.; Jacinto-Hernandez, C.; Jimenez-Martinez, C., Angiotensin-converting enzyme- 
480 inhibitory activity in protein hydrolysates from normal and anthracnose disease-damaged Phaseolus 481 vulgaris seeds. J. Sci. Food Agric. 2013, 93, 961-966.

482 (32) Sirtori, C. R.; Galli, C.; Anderson, J. W.; Sirtori, E.; Arnoldi, A., Functional foods for 483 dyslipidaemia and cardiovascular risk prevention. Nutr. Res. Rev. 2009, 22, 244-261.

484 (33) Akillioglu, H. G.; Karakaya, S., Effects of heat treatment and in vitro digestion on the 485 Angiotensin converting enzyme inhibitory activity of some legume species. Eur. Food Res. Technol. 486 2009, 229, 915-921.

487 (34) Jakubczyk, A.; Baraniak, B., Activities and sequences of the angiotensin I-converting enzyme 488 (ACE) inhibitory peptides obtained from the digested lentil (Lens culinaris) globulins. Int. J. Food Sci. 489 Technol. 2013, 48, 2363-2369.

490 (35) Kuba, M.; Tana, C.; Tawata, S.; Yasuda, M., Production of angiotensin I-converting enzyme 491 inhibitory peptides from soybean protein with Monascus purpureus acid proteinase. Process Biochem. 492 2005, 40, 2191-2196.

493 (36) Ou, B. X.; Huang, D. J.; Hampsch-Woodill, M.; Flanagan, J. A.; Deemer, E. K., Analysis of 494 antioxidant activities of common vegetables employing oxygen radical absorbance capacity (ORAC) 495 and ferric reducing antioxidant power (FRAP) assays: A comparative study. J. Agric. Food Chem. 2002, $496 \quad 50,3122-3128$.

497 (37) Carrasco-Castilla, J.; Javier Hernandez-Alvarez, A.; Jimenez-Martinez, C.; Jacinto-Hernandez, 498 C.; Alaiz, M.; Giron-Calle, J.; Vioque, J.; Davila-Ortiz, G., Antioxidant and metal chelating activities of 499 peptide fractions from phaseolin and bean protein hydrolysates. Food Chem. 2012, 135, 1789-1795.

500 (38) Sarmadi, B. H.; Ismail, A., Antioxidative peptides from food proteins: A review. Peptides 2010, $501 \quad 31,1949-1956$. 
502 (39) Elias, R. J.; Kellerby, S. S.; Decker, E. A., Antioxidant activity of proteins and peptides. Crit. 503 Rev. Food Sci. Nutr. 2008, 48, 430-441.

504 (40) Darmawan, R.; Bringe, N. A.; de Mejia, E. G., Antioxidant Capacity of Alcalase Hydrolysates 505 and Protein Profiles of Two Conventional and Seven Low Glycinin Soybean Cultivars. Plant Foods 506 Hum. Nutr. 2010, 65, 233-240.

507 (41) Keller, B. O.; Li, L., Discerning matrix-cluster peaks in matrix-assisted laser 508 desorption/ionization time-of-flight mass spectra of dilute peptide mixtures. J. Am. Soc. Mass Spectr $5092000,11,88-93$.

510 (42) Harris, W. A.; Janecki, D. J.; Reilly, J. P., Use of matrix clusters and trypsin autolysis fragments 511 as mass calibrants in matrix-assisted laser desorption/ionization time-of-flight mass spectrometry. Rapid 512 Commun. Mass Sp. 2002, 16, 1714-1722.

513 (43) Cheung, H. S.; Wang, F. L.; Ondetti, M. A.; Sabo, E. F.; Cushman, D. W., Binding of peptide 514 substrates and inhibitors of angiotensin-converting enzyme. Importance of the COOH-terminal dipeptide 515 sequence. J. Biol. Chem. 1980, 255, 401-407.

516 (44) Elias, R. J.; Bridgewater, J. D.; Vachet, R. W.; Waraho, T.; McClements, D. J.; Decker, E. A., 517 Antioxidant mechanisms of enzymatic hydrolysates of $\beta$-lactoglobulin in food lipid dispersions. $J$. 518 Agric. Food Chem. 2006, 54, 9565-9572.

519 (45) Hernández-Ledesma, B.; Dávalos, A.; Bartolomé, B.; Amigo, L., Preparation of antioxidant 520 enzymatic hydrolysates from $\alpha$-lactalbumin and $\beta$-lactoglobulln. Identification of active peptides by 521 HPLC-MS/MS. J. Agric. Food Chem. 2005, 53, 588-593.

522 (46) Foltz, M.; van Buren, L.; Klaffke, W.; Duchateau, G. S. M. J. E., Modeling of the Relationship 523 between Dipeptide Structure and Dipeptide Stability, Permeability, and ACE Inhibitory Activity. J. 524 Food Sci. 2009, 74, H243-H251. 
525 (48) Martinez-Maqueda, D.; Miralles, B.; Recio, I.; Hernadez-Ledesma, B. Antihypertensive peptides 526 from food proteins: a review. Food Funct. 2012, 3, 350-361.

527 (47) Wu, J.; Yuan, L.; Aluko, R. E. Restriction of the in Vitro Formation of Angiotensin II by Leucinyl528 Arginyl-Tryptophan, a Novel Peptide with Potent Angiotensin I-Converting Enzyme Inhibitory Activity. 529 Biosci. Biotechnol. Biochem. 2006, 70, 1277-1280.

\section{FIGURE CAPTIONS}

534 Figure 1. Degree of hydrolysis (DH) of lentil proteins by different proteases and hydrolysis times. The 535 experiments were performed in duplicate. Bars indicate the standard deviation A: Alcalase; S: Savinase; 536 P: Protamex; C: Corolase 7089.

537 Figure 2. Sodium-dodecyl sulphate polyacrylamide gel electrophoresis (SDS-PAGE) profiles of lentil 538 hydrolyzates obtained by different proteases and hydrolysis times. Panel A, Alcalase; Panel B, Savinase; 539 Panel C, Protamex; and Panel D, Corolase 7089 hydrolyzates. Lane 1: molecular weight marker Mark $540 \quad 12^{\mathrm{TM}}$; Lanes 2-8: $0,1,2,3,4,5$, and 6 h of hydrolysis, respectively.

541 Figure 3. Peptide mass fingerprint of $3 \mathrm{kDa}$ permeates of lentil hydrolyzates. Panel A, A4 hydrolyzate; 542 Panel B, S2 hydrolyzate. The mass spectra were obtained by MALDITOF in the reflector mode for 543 positive ions. The respective table insets show differential peptide masses observed for each 544 hydrolyzate.

545 Figure 4. Stability to gastrointestinal digestion of ACE inhibitory and antioxidant activity of $3 \mathrm{kDa}$ 546 permeates of A3 and S2 hydrolyzates. Lines represent ACE-inhibitory activity and columns show 
547 antioxidant activity before and after in vitro gastrointestinal digestion. * indicate statistical difference at $548 \mathrm{P}<0.05 ; * *$ indicate statistical difference at $\mathrm{P}<0.001$ (Duncan test) 
Table 1. Effect of hydrolysis time and protease type on ACE-inhibitory activity of lentil hydrolysates

\section{ACE Inhibition (\%) ${ }^{1}$}

\begin{tabular}{ccccc}
\hline Time (h) & $\mathrm{A}$ & $\mathrm{S}$ & $\mathrm{P}$ & $\mathrm{C}$ \\
\hline $\mathbf{0}$ & $20.34 \pm 1.48^{\mathrm{A}}{ }_{\mathrm{a}}$ & $20.49 \pm 0.53^{\mathrm{A}}{ }_{\mathrm{a}}$ & $21.20 \pm 4.02^{\mathrm{A}}{ }_{\mathrm{a}}$ & $20.17 \pm 0.1^{\mathrm{A}}{ }_{\mathrm{a}}$ \\
$\mathbf{1}$ & $64.37 \pm 1.57^{\mathrm{B}}{ }_{\mathrm{c}}$ & $56.73 \pm 1.54^{\mathrm{B}}{ }_{\mathrm{b}}$ & $46.52 \pm 3.84^{\mathrm{D}}{ }_{\mathrm{a}}$ & $41.51 \pm 0.12^{\mathrm{D}}{ }_{\mathrm{a}}$ \\
$\mathbf{2}$ & $64.37 \pm 0.25^{\mathrm{B}}{ }_{\mathrm{c}}$ & $63.35 \pm 2.41^{\mathrm{C}}{ }_{\mathrm{c}}$ & $41.04 \pm 1.17^{\mathrm{CD}}{ }_{\mathrm{a}}$ & $50.57 \pm 5.45^{\mathrm{E}}{ }_{\mathrm{b}}$ \\
$\mathbf{3}$ & $71.65 \pm 0.74^{\mathrm{D}}{ }_{\mathrm{c}}$ & $59.08 \pm 0.42^{\mathrm{B}}{ }_{\mathrm{b}}$ & $38.10 \pm 1.90^{\mathrm{C}}{ }_{\mathrm{a}}$ & $36.79 \pm 2.28^{\mathrm{CD}}{ }_{\mathrm{a}}$ \\
$\mathbf{4}$ & $70.37 \pm 2.93^{\mathrm{D}}{ }_{\mathrm{c}}$ & $59.08 \pm 1.61^{\mathrm{B}}{ }_{\mathrm{b}}$ & $40.50 \pm 1.42^{\mathrm{C}}{ }_{\mathrm{a}}$ & $36.23 \pm 4.42^{\mathrm{CD}}{ }_{\mathrm{a}}$ \\
$\mathbf{5}$ & $68.00 \pm 2.36 \mathrm{~B}^{\mathrm{CD}}{ }_{\mathrm{c}}$ & $57.41 \pm 2.08^{\mathrm{B}}{ }_{\mathrm{b}}$ & $31.86 \pm 1.11^{\mathrm{B}}$ & $33.19 \pm 3.46^{\mathrm{BC}}{ }_{\mathrm{a}}$ \\
& $67.74 \pm 1.98^{\mathrm{BC}}{ }_{\mathrm{c}}$ & $56.33 \pm 2.23^{\mathrm{B}}{ }_{\mathrm{b}}$ & $31.23 \pm 0.04^{\mathrm{B}}$ & $28.37 \pm 1.19^{\mathrm{B}}{ }_{\mathrm{a}}$
\end{tabular}

$\overline{\text { Data indicate mean value } \pm \text { standard deviation of two independent experiments. Different uppercase letters }}$ within column are significantly different $(\mathrm{P}<0.05$, Duncan's test). Different lowercase letters within row are significantly different $(\mathrm{P}<0.05$, Duncan's test $)$.

A: Alcalase, S: Savinase, P: Protamex, C: Corolase 7089.

Protein concentration of samples in the ACE inhibition assay was $0.5 \mathrm{mg} / \mathrm{mL}$. 
Table 2. Effect of hydrolysis time and protease type on antioxidant activity of lentil hydrolysates

\begin{tabular}{ccccc}
\hline \multirow{2}{*}{ Time (h) } & & \multicolumn{3}{c}{ ORAC $(\mu$ mol Trolox/mg protein) } \\
\cline { 2 - 5 } & $\mathrm{A}$ & $\mathrm{S}$ & $\mathrm{P}$ & $\mathrm{C}$ \\
\hline 0 & $0.43 \pm 0.02^{\mathrm{A}}{ }_{\mathrm{a}}$ & $0.43 \pm 0.02^{\mathrm{A}}{ }_{\mathrm{a}}$ & $0.44 \pm 0.02^{\mathrm{A}}{ }_{\mathrm{a}}$ & $0.44 \pm 0.03^{\mathrm{A}}{ }_{\mathrm{a}}$ \\
1 & $0.57 \pm 0.03^{\mathrm{B}}{ }_{\mathrm{bc}}$ & $0.52 \pm 0.03^{\mathrm{BC}}{ }_{\mathrm{a}}$ & $0.58 \pm 0.03^{\mathrm{E}}{ }_{\mathrm{c}}$ & $0.53 \pm 0.04^{\mathrm{BC}}{ }_{\mathrm{ab}}$ \\
2 & $0.64 \pm 0.2^{\mathrm{C}}{ }_{\mathrm{c}}$ & $0.81 \pm 0.02^{\mathrm{F}}{ }_{\mathrm{d}}$ & $0.56 \pm 0.03^{\mathrm{CD}}{ }_{\mathrm{b}}$ & $0.50 \pm 0.04^{\mathrm{B}}{ }_{\mathrm{a}}$ \\
3 & $0.62 \pm 0.03^{\mathrm{C}}{ }_{\mathrm{b}}$ & $0.75 \pm 0.07^{\mathrm{E}}{ }_{\mathrm{c}}$ & $0.55 \pm 0.04^{\mathrm{BCD}}{ }_{\mathrm{a}}$ & $0.54 \pm 0.04^{\mathrm{CD}}{ }_{\mathrm{a}}$ \\
4 & $0.70 \pm 0.05^{\mathrm{D}}{ }_{\mathrm{c}}$ & $0.62 \pm 0.05^{\mathrm{D}}{ }_{\mathrm{b}}$ & $0.49 \pm 0.02^{\mathrm{B}}{ }_{\mathrm{a}}$ & $0.59 \pm 0.02^{\mathrm{D}}{ }_{\mathrm{b}}$ \\
5 & $0.70 \pm 0.04^{\mathrm{D}}{ }_{\mathrm{b}}$ & $0.56 \pm 0.05^{\mathrm{C}}{ }_{\mathrm{a}}$ & $0.53 \pm 0.03^{\mathrm{BC}}{ }_{\mathrm{a}}$ & $0.55 \pm 0.03^{\mathrm{CD}}{ }_{\mathrm{a}}$ \\
6 & $0.57 \pm 0.03^{\mathrm{B}}{ }_{\mathrm{c}}$ & $0.49 \pm 0.05^{\mathrm{B}}{ }_{\mathrm{a}}$ & $0.51 \pm 0.04^{\mathrm{AB}}{ }_{\mathrm{ab}}$ & $0.53 \pm 0.02^{\mathrm{BC}}{ }_{\mathrm{bc}}$ \\
\hline
\end{tabular}

$\overline{\text { Data indicate mean value } \pm \text { standard deviation of two independent experiments. Different uppercase letters }}$ within column are significantly different $(\mathrm{P}<0.05$, Duncan's test). Different lowercase letters within row are significantly different $(\mathrm{P}<0.05$, Duncan's test).

A: Alcalase, S: Savinase, P: Protamex, C: Corolase 7089. 
Table 3. Amino acid sequences found in $3 \mathrm{kDa}$ permeates of S2 lentil hydrolysates

\begin{tabular}{|c|c|c|c|}
\hline $\mathrm{MH}^{+}$(Da) & Peptide sequence & Protein & Accession \\
\hline 1252.78 & DLPVLRWL & Legumin A & $388256 ; 483449 ; 126161$ \\
\hline 1252.78 & DLPVLRWLKL & Legumin A & $388256 ; 483449 ; 126161$ \\
\hline 1927.07 & DRRQEINKENVIVKVS & Allergen Len c 1.0102 & Q84UI0 \\
\hline 835.47 & EGGLLLPH & Convicilin & Q9M3X8 \\
\hline 1982.11 & EGSLLLPHYNSRAIVIVT & Vicilin & $137582 ; 1297072$ \\
\hline 1876.87 & FEGTVFENGIDA_AYRST & Albumin-2 & 113570 \\
\hline 977.57 & INDKYVLL & Albumin-2 & P86782 \\
\hline 1237.72 & LFINDKYYVLL & Albumin-2 & P86782 \\
\hline 1002.55 & NEDVIVKVS & Allergen Len c 1.0101 & Q84UI1 \\
\hline 1831.99 & NLERGDTIKLPAGTIAYY & Allergen Len c 1.0101 & Q84UI1;Q84UI0 \\
\hline 1945.07 & NLERGDTIKLPAGTIAYL & Allergen Len c 1.0101 & Q84UI1;Q84UI0 \\
\hline 2245.15 & NRFQTLYENENGHIRLLQ & allergen Len c 1.0101 & 42414629;29539109;29539111 \\
\hline 1499.84 & QEINKENVIVKVS & Allergen Len c 1.0102 & Q84UI0 \\
\hline 2131.10 & RFQT $\underline{\text { LYENENGHIRLLQ }}$ & Allergen Len c 1.0101 & $42414629 ; 29539109 ; 29539111$ \\
\hline 1269.69 & RLSAEYVRLY & Legumin type B & $126164 ; 126166 ; 126170$ \\
\hline 1725.01 & RRQEINKENVIVKV & Allergen Len c 1.0102 & Q84UI0 \\
\hline 1927.07 & RRQEINKENVIVKVS & Allergen Len c 1.0102 & Q84UI0 \\
\hline 1098.63 & SLDLPVLRW & legumin A & $483449 ; 126161$ \\
\hline 1212.72 & SLDLPVLRWL & legumin A & $483449 ; 126162$ \\
\hline 1421.80 & SVEIKEGSLLLPH & Vicilin & $137582 ; 1297072$ \\
\hline 1698.91 & SVEIKEGSLLLPHYN & Vicilin & $137582 ; 1297072$ \\
\hline 1785.94 & SVEIKEGSLLLPHYNS & Vicilin & $137582 ; 1297072$ \\
\hline 1377.74 & SVEINEGGLLLPH & Convicilin & 7688242 \\
\hline 1540.80 & SVEINEGGLLLPHY & Convicilin & Q9M3X8 \\
\hline 1897.98 & SVEINEGGLLLPHYNSR & Convicilin & Q9M3X8 \\
\hline 1817.93 & SWNLQNGERANVVIAF & Lectin & Q93WH6;Q93X49 \\
\hline 1312.76 & TSLDLPVLRWL & legumin A & $483449 ; 126161$ \\
\hline 1512.88 & TVTSLDLPVLRWL & legumin A & $483449 ; 126161$ \\
\hline 2538.43 & VEIKEGSLLLPHYNSR & Vicilin & $137582 ; 1297072$ \\
\hline 1290.70 & VEINEGGLLLPH & Convicilin & 7688242 \\
\hline 1634.91 & VNSVEIKEGSLLLPH & Vicilin & $137582 ; 1297072$ \\
\hline 2155.15 & VNSVEIKEGSLLLPHYNSR & Vicilin & $137582 ; 1297072$ \\
\hline
\end{tabular}

Bolded and underlined sequence regions correspond to reported ACE-inhibitory and antioxidant activity, respectively, in BIOPEP (http://www.uwm.edu.pl/biochemia/index.php/pl/biopep) and Wu et al. ${ }^{48}$ 
Figure 1

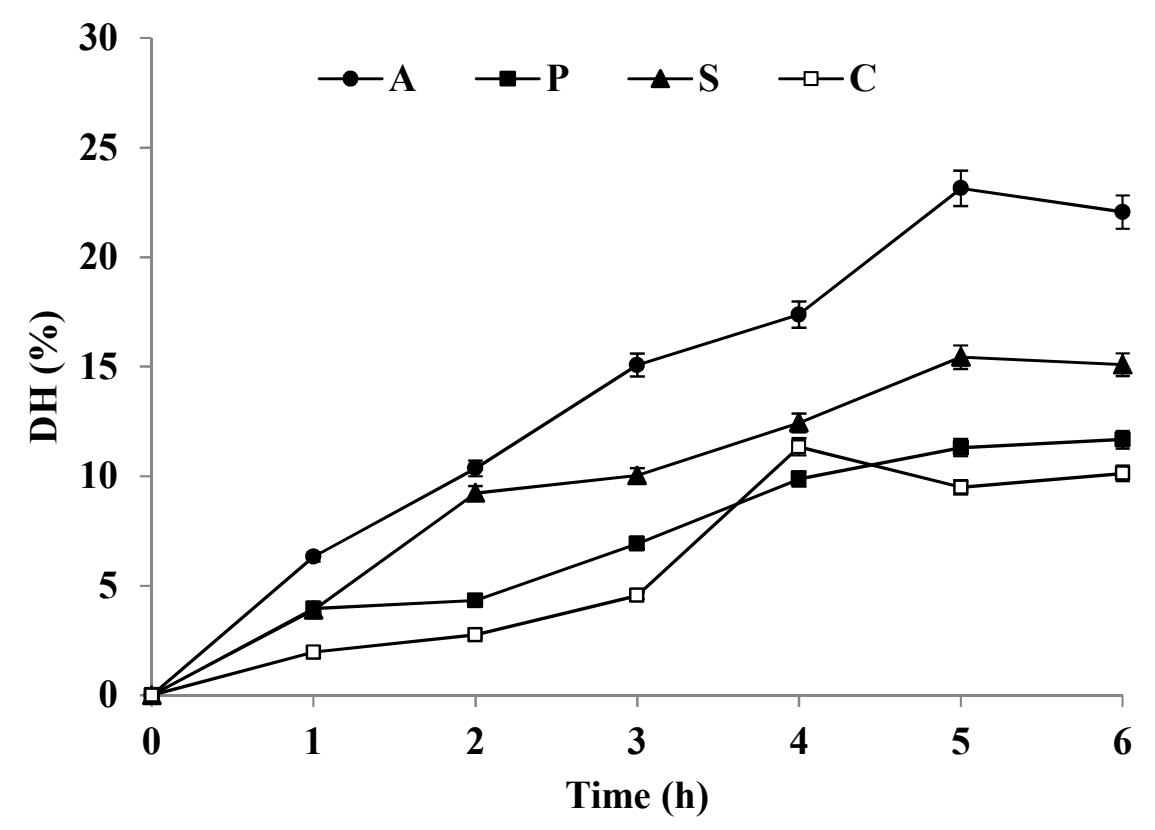


Figure 2

A

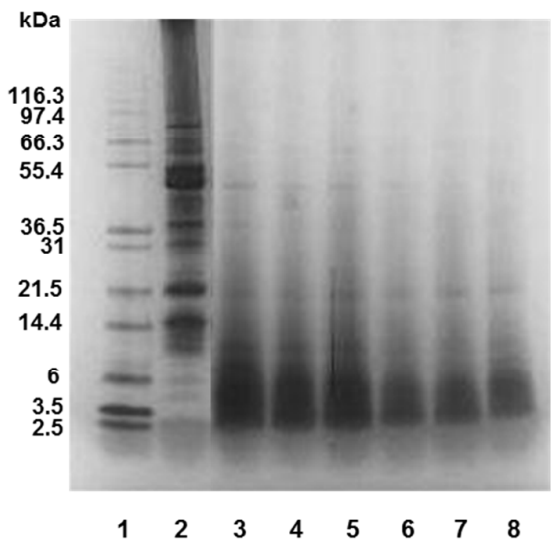

B

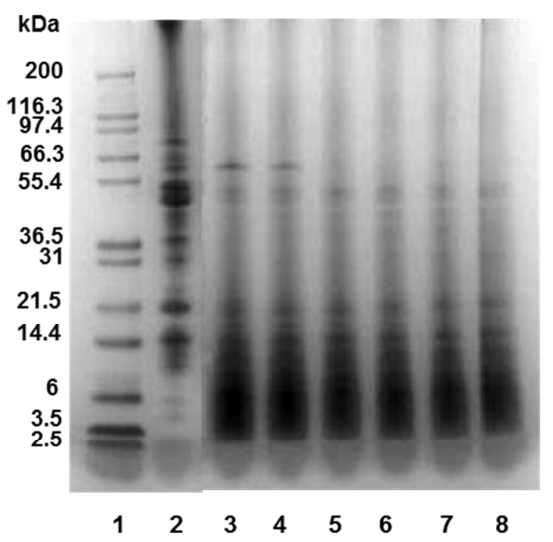

C

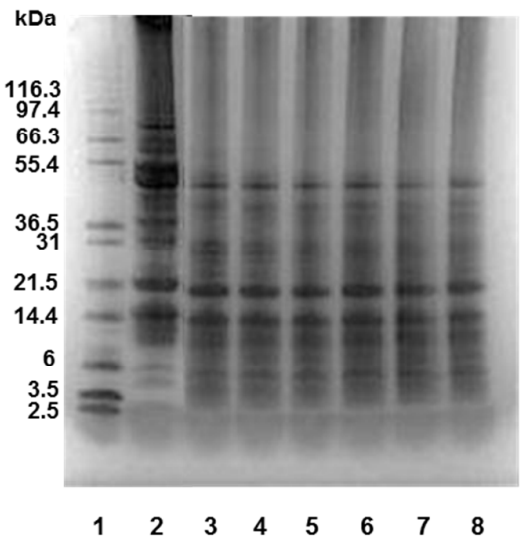

D

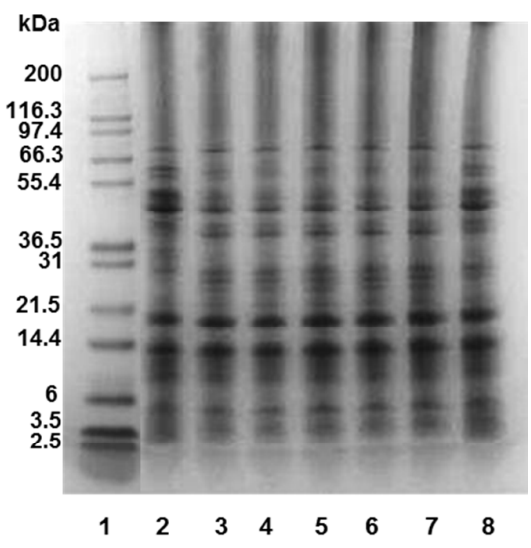


Figure 3.

A

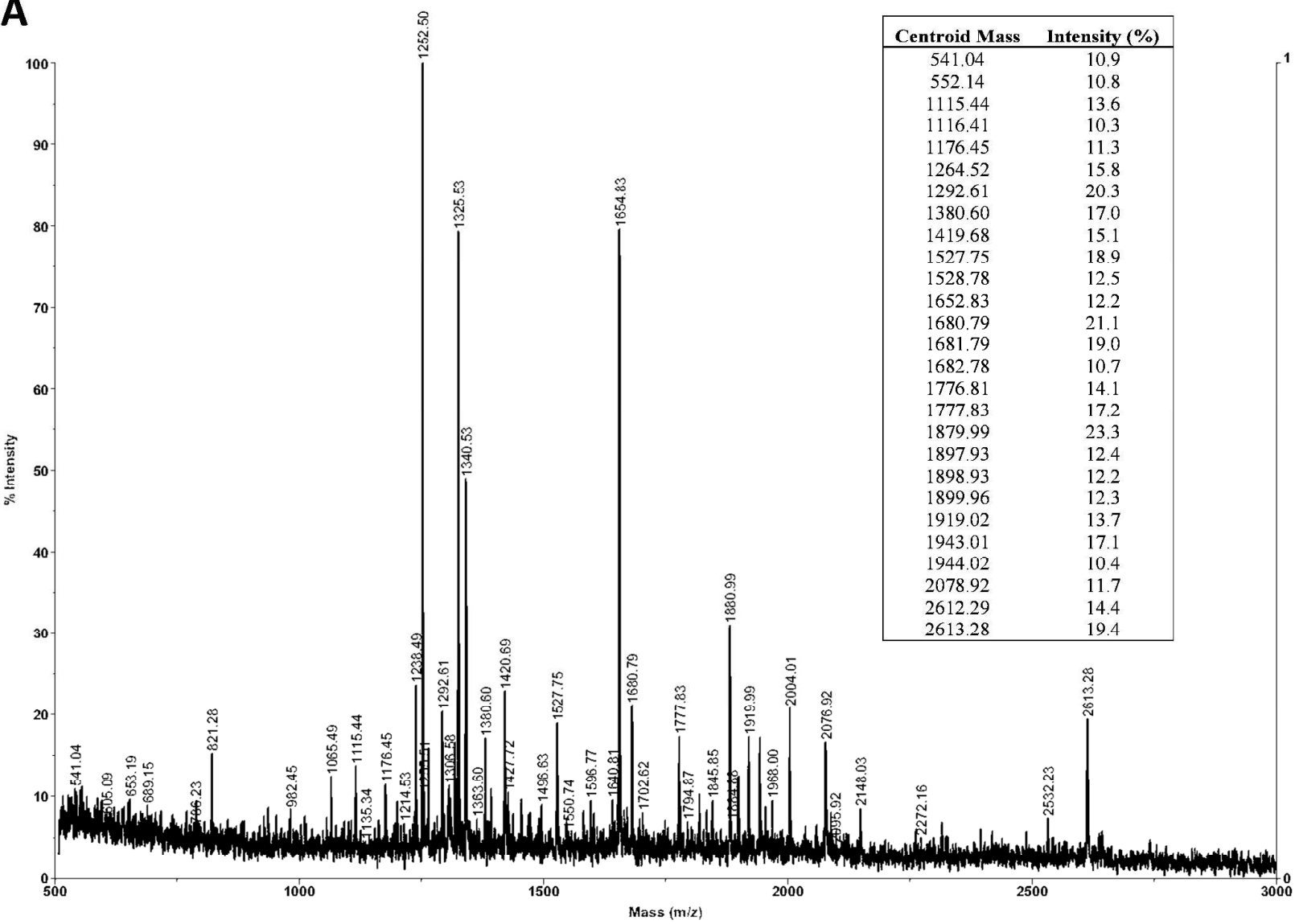

B

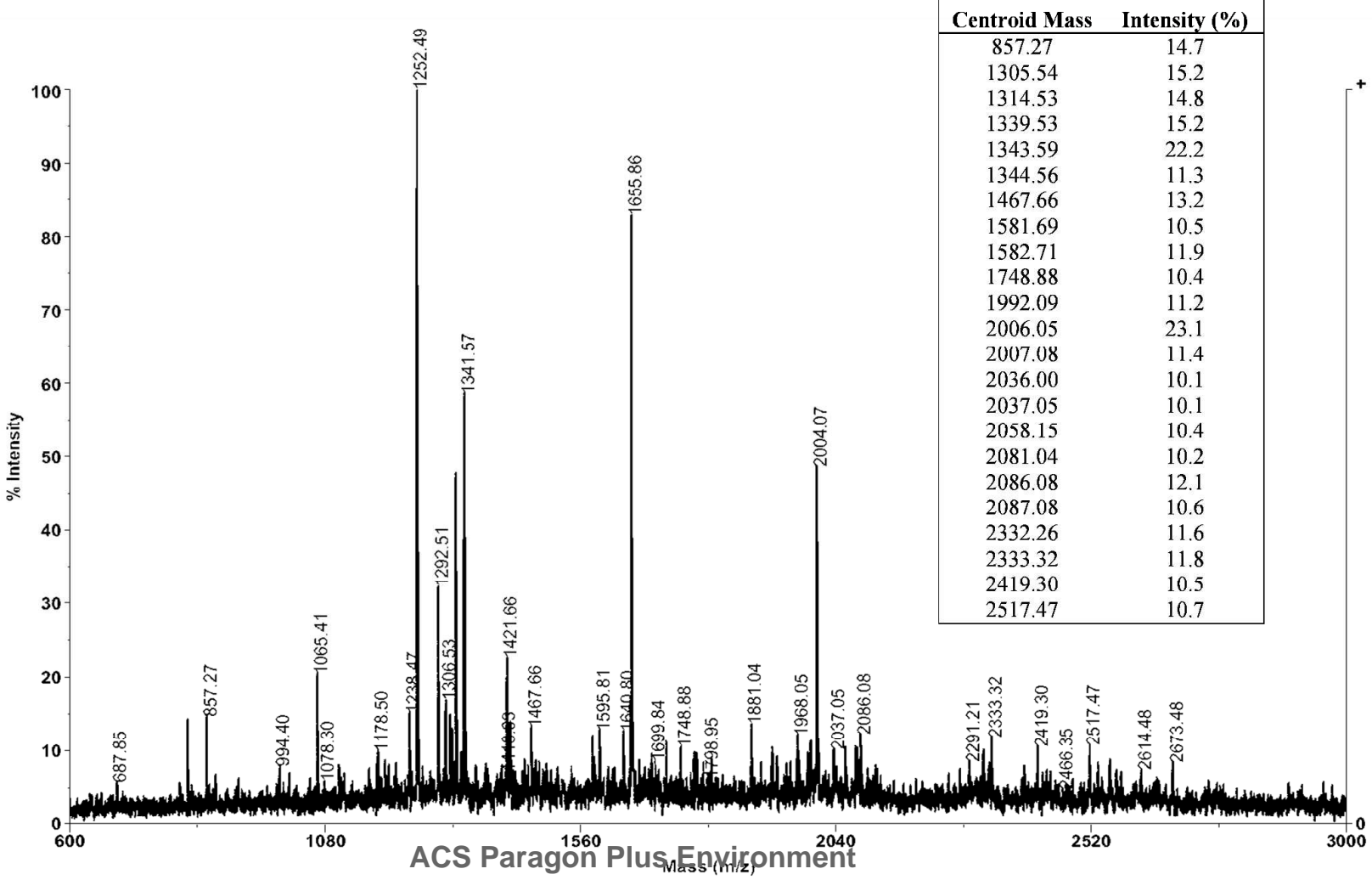


Figure 4.

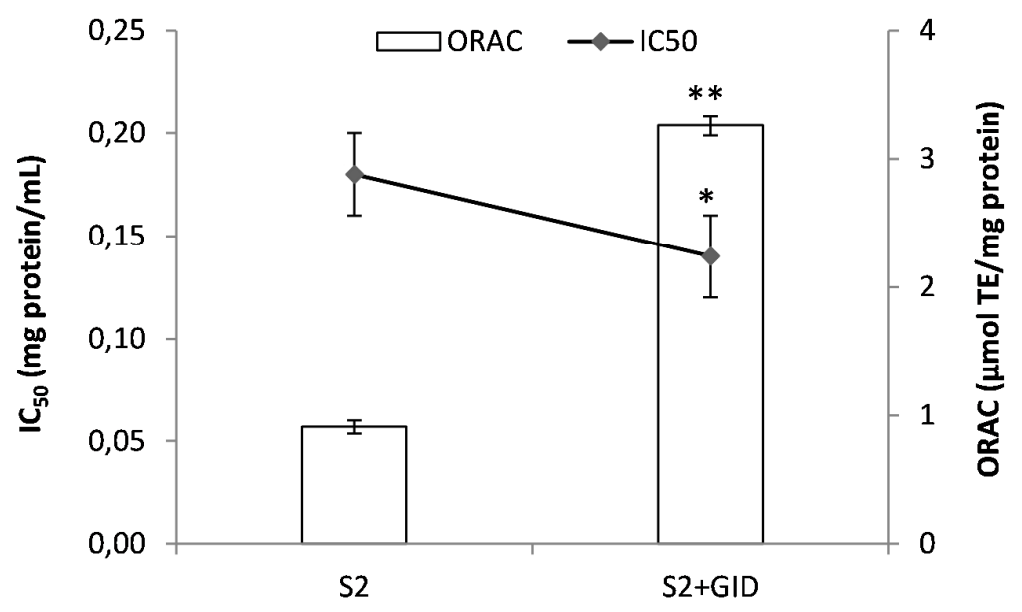


TABLE OF CONTENT GRAPHIC

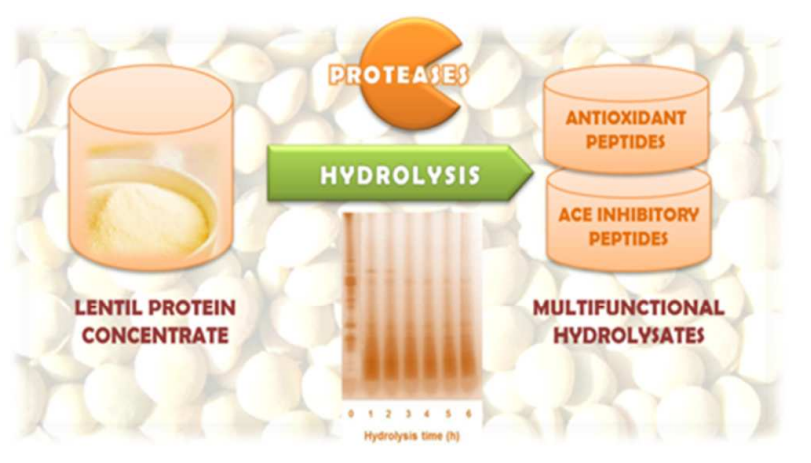

